\title{
THE FIRST PLACARD OF
}

\section{THE ARMADILLAN ABSOLUTISTS}

\section{Literary activity at Victoria University College 1947-1951}

\author{
STEPHEN HAMILTON
}

I

A

T THE START of the 1946

academic year enrolments at Wellington's Victoria University College were swollen by an estimated 700 returning servicemen eager to take advantage of the newly instituted rehabilitation schemes. Many of these men - older, more experienced and more mature than their younger counterparts at the college - brought with them political idealism and a fervent hope that the mistakes of the 1930s would not be repeated in the post-war era. An Ex-Servicemen's Society was soon formed, its 200 members eager to distance themselves from a proposal to set up a VUC branch of the Returned Servicemen's Association. ${ }^{2}$ A number of these same 'rehabbers', including Ron Smith, Harold Dowrick, Jim Winchester, Dorian Saker, Harry Evison, and Alec McLeod, were also instrumental in forming the VUC Socialist Club. This soon became active on a number of issues, from improving the tobacco ration for returned servicemen to marching in opposition to compulsory military training. On 30 July
1947, leading members of the club became the first New Zealand students to be arrested for street protest after they marched through central Wellington to demonstrate against Dutch military action in Indonesia.

In the midst of all this political ferment there were also stirrings of a literary nature. In late 1947, in a report in the Students' Association's annual review on the activity of the College's revived Literary Society, mention was made of the establishment of three study groups; on New Zealand poetry, William Blake and Elizabethan drama. ${ }^{3}$ Members of the society included Pat Wilson, Bill Oliver, Alistair Campbell, Eric Schwimmer, Lorna Clendon, Bill Mabbitt, Gordon Orr, Harry Orsman, Elizabeth Entrican, Judith Wild, Lorna Clendon and Geoffrey Datson. Of these, Wilson, Oliver, Thomson, Campbell, Wild, Clendon and Schwimmer were chief among those responsible for the production of the society's Broadsheet, first published in May 1947, and it was largely through their efforts that that ephemeral publication was transformed into Hilltop and then Arachne.
II

YCLOSTYLED AND STAPLED,
there were no more than five issues of Broadsheet, of from nine to twelve pages each. ${ }^{4}$ The first number opens with an editorial by Oliver in which he sets out the straightforward objectives of the Society and its magazine. The official publications of the Students' Association, Spike and Salient, are seen as lacking critical content, a deficiency the Society intends to correct. The recently founded Landfall must also be figured into Oliver's statement. As James Bertram commented in his 1954 account of literary activity at Victoria, this " national" New Zealand quarterly ... provided both encouragement to young writers, and a norm to vary against. ${ }^{5}$ However, while there was certainly a strong element of resistance and even literary subversion among those responsible for Broadsheet and its successors, publication in the highly regarded quarterly remained their most prized goal. Several soon had work accepted by Landfall's 
editor Charles Brasch, who, as will be seen, in turn encouraged them in their efforts to publish their own little magazines.

The most significant contribution to the first issue of Broadsheet is a poem by Alistair Campbell, 'Love Poem IV,' part of an ongoing sequence of poems, of which more were to appear in the issue of Spike for 1948 and in the first issue of Hilltop in April 1949. Campbell's only other contribution to Broadsheet, although there is some uncertainty over the attribution, is an untitled poem printed over the initials 'C.A.S.' in the issue for June 1948, that given the title First Placard of the Armadillan Absolutists. Neither of these poems have been republished. Pat Wilson contributed a poem to the first issue of Broadsheet, and two poems to the final issue. Wilson also had at least some involvement in the writing of 'On the Necessity for a National Literature,' published anonymously in the first issue. ${ }^{6}$

The second issue, dated August 1947, opens with an editorial by Eric Schwimmer. Born in Amsterdam in 1923, he was living in Indonesia with his parents at the start of the Second World War. After arriving in New Zealand with his family in 1940, he graduated from Victoria with a BA in Classics-in 1948 before going on to a career as an anthropologist both here and in Canada. His interest in European and particularly French existentialist literature and his concern with theory, unusual at the time, gave him some standing as 'the intellectual of the group'.? In his Broadsheet editorial Schwimmer responds to the first and second issues of Landfall, taking issue with what he perceives as Brasch's too simplistic and deterministic view of the development of New Zealand culture. He recently described the dispute as 'a quarrel with a mechanical view of causality which links supposed realia like the "landfall" of the British to New Zealand poetry as a necessary and sufficient determinant. ${ }^{\text {s }}$

The undated next issue of Broadsheet - the third - carries the title First Placard of the Armadillan Absolutists and a cover illustration by Alistair Campbell featuring a bandaged hand with hanging from it what Campbell later described as, in accordance with the title of the issue, a miniature armadillo (although, with its numerous small legs and obvious antennae, this appears to be a common slater or wood louse). ${ }^{9}$ The drawing is accompanied by some deliberately obscure, Pound-like lines penned by Bill Oliver: 'Only the shy return / After the dawn.' Ostensibly serious but in fact nothing less than a deliberate literary hoax, the Placard's announced intention was 'to start a new "school" of poetry' based on the premise that '[1]anguage is an absolute. What is stated in poetry is stated for all time in the only possible terms. ${ }^{10}$ The poems of the brilliant Australian literary fraud, Ern Malley, published in 1944, were prefaced by similar gnomic utterances. The Malley hoax had been discussed in an article in Spike later in the same year, signed simply 'Triad'. ${ }^{11}$

The inclusion of an article by 'S.E.H.' (identified by Bill Oliver and Pat Wilson as Eric Schwimmer although Schwimmer disputes this) ${ }^{12}$ on the New York poet Harry Roskolenko, citing him as 'one of the chief precursors of the movement of which this placard is an expression,' and a poem by Pat Wilson (signed 'C.W.B.'), titled 'Homage to Roskolenko, ${ }^{\prime 13}$ indicates a tentative link between the Placard and the Ern Malley hoax. Roskolenko, who styled himself 'first poet of the Apocalypse, ${ }^{14}$ was stationed with the United States Army in Sydney during the war. He was so impressed with the Malley poems that he arranged for three of them to be published in a special Australian issue of the New York journal Voices. Max Harris, editor and publisher of the Malley poems and of the periodical Angry Penguins, provided a commentary for Voices and advised Roskolenko on selection, assisted by C.B. Christensen of Meanjin Papers, Cecily Crozier of Comment, and R.G. Howarth of Southerly. ${ }^{15}$ Roskolenko also had two volumes of poetry published in Australia, at least one of which was familiar to

Schwimmer. ${ }^{16}$

Pat Wilson later recalled that Schwimmer asked him to choose, more or less at random, the quotations used in the Roskolenko article from a selection initially made by Schwimmer. Wilson also recalls that his 'Homage to Roskolenko' was written at Schwimmer's request:

[It] has no connection whatsoever with its (Erik's) title. It's not in any sense a 'homage' addressed to someone, real or imaginary; it is merely a piece of what I used to call 'atmospherics,' written in a sort of 
doggerel, and almost completely meaningless although it reads like sense.

Wilson also rightly points out that the fact that Roskolenko was a real poet makes:

'the Placard not an Ern Malley type hoax but the opposite of one.... 'Ern Malley' didn't in fact exist, but he sounded like someone who did; by contrast 'Harry Roskolenko' sounded ... like some one who didn't exist. ${ }^{\prime 7}$

Schwimmer cannot now recall precisely why Roskolenko played such an important part in the issue. He disagrees that the citing of Roskolenko was part of a 'search for legitimacy or planned hoaxing as everything [in the issue] was a spontaneous joke. ${ }^{18}$ The American poet visited Auckland in 1946 where he met David Ballantyne, then a journalist with the Auckland Star. Ballantyne introduced Roskolenko to Frank Sargeson, Maurice Duggan and others. ${ }^{19}$ Neither Schwimmer nor any members of the Broadsheet group met Roskolenko, and indeed Oliver and Campbell deny any knowledge of him at the time beyond Schwimmer's portentous attributions in the Placard.

According to Alistair Campbell, the Placard was produced when he, Bill Oliver, and Pat Wilson went around to Eric Schwimmer's home and 'decided to have a bit of fun.' A story, 'Death by Dissertation', was written by the group as a whole in the manner of a party-game with each writer contributing a paragraph with little or no reference to what had gone before. Other contributions were composed in similar ways. ${ }^{20}$ Apparently, several people not in on the joke took the Placard seriously. The next issue of Broadsheet opened with an editorial titled 'An Explanation,' probably written by Eric Schwimmer, which begins by declaring that ' $[\mathrm{t}] \mathrm{he}$ Armadillans are quite unpenitent', before going on to defend the work in the Placard. This fourth issue also carries a number of poems, including two by Brian Bell, and an appropriately ironic review by 'O.D.' of the first issue of Bookie, the affectionate satire on Book written and published by Bob Gormack of the Nag's Head Press. A report on the activities of the Literary Society's New Zealand literature group for the first half of 1948 gives some indication of the enthusiasm among members for NZ Lit., with which many had been unfamiliar prior to attending university:

This group has already discussed James K. Baxter (Pat Wilson); four Auckland Writers - Fairburn, Mason, Mulgan and Sargeson (Bill Shires); Arnold Cork, Geoffrey Pollett, and Count Geoffrey ... de Montalk, ... Pretender to the Throne of Poland (Tony MurrayOliver); and at the most recent meeting selected passages were read by those present .... .

On July 22nd Mr Schwimmer will speak on Frank Sargeson, and at subsequent meetings there will be, among other speakers, Mr W.H. Oliver on Basil Dowling; Mr C.W. Strathern on Thomas Bracken; Mr P. S. Wilson on The Old Clay Patch; and $\mathrm{Mr}$ A.St.C.M. Murray-Oliver on
Douglas Stewart.

The colophon to the issue announced that it was 'Printed and Published by the Victoria University College Literary Society, July 17 th, 1948. ${ }^{21}$

The final number of Broadsheet appeared the following month and was sold around the college for sixpence. It opened with an unsigned editorial which stated in part that Broadsheet 'exists because people write for us and we like printing their work.' Despite the ingenuous nature of this statement, it is possible to detect in the pages of this final issue an immanent (if not yet actual) increase in the thoughtfulness and seriousness of the enterprise. Among a number of anonymous poems were several by Pat Wilson, plus articles by Eric Schwimmer and R.T. Robertson. The first issue of Hilltop, edited by John Mansfield Thomson, appeared early the following year.

\section{III}

$\mathrm{H}$ ILLTOP MARKED A significant step forward from Broadsheet, in terms both of the contents and of the production quality of the magazine. Literary Society members Pat Wilson and John Thomson sought prices for the production of a forty-page magazine from several Wellington printers, finally accepting a quotation submitted by McKenzie Thornton Cooper for ' 600 copies Crown 4 to. 40 pages Self Cover printed on Newsprint, 2 colums [sic] 10 point for Forty-five pounds 
fifteen shillings. ${ }^{22}$ The decision to use a local Wellington printer rather than presses such as Caxton or Pegasus was partly one of expediency, but also may have been motivated by a desire to break away from Christchurch's near monopoly on literary printing. This in turn may be seen as part of the critical and stylistic break by the new generation from the influence of the established New Zealand poets, represented most explicitly by Allen Curnow, Denis Glover and Caxton publications such as the 1945 Book of New Zealand Verse. ${ }^{23}$

Unfortunately, the result was less than pleasing. McKenzie Thornton Cooper had a very limited range of typefaces and Thomson was forced to select the best of these, Century, for the new publication. The first number was pastedup over an issue of the New Zealand Funeral Director, supplied by the printer on the grounds that it was the same size as the proposed literary magazine. As a result, Roy Parsons, who supported the magazine through advertising, was very reluctant to sell copies of Hilltop in his bookshop, regarding it as having the appearance of a parish magazine. ${ }^{24}$ After Frank Stockman, an architecture student associated with the Literary Society, criticised the layout of the first issue, Thomson engaged him to advise on design. While little could be done about improving the typeface, Stockman did commission John Drawbridge of Wellington Teachers' College to design a cover. The result appeared on the two subsequent issues, both of which are also tangibly improved in other ways by the influence of
Stockman.

Thomson, as secretary of the Society, solicited subscriptions to the proposed magazine in a circular letter. His comments therein shed light on the motivations behind the shift to a more professional format.

In the past we have sponsored a cyclostyled 'Broadsheet' containing verse and articles by the members of the society and their friends, but the transient character of these sheets together with their unpleasant appearance and the difficulties and discouragements involved in their printing has decided us to end these experiments and to engage a professional printer. The limited circulation was also a disadvantage and we would now like to provide more opportunity for the young writers in Wellington and at Victoria - several of whom have had work printed in Landfall and others of the country's periodicals. ${ }^{25}$

Ideas for a title for the new magazine were also canvassed. Alistair Campbell suggested 'Notornis,' in celebration of the recently rediscovered Takahe. Pat Wilson proposed 'Christopher's Paper' and a dummy subscription form using this title was prepared. However, in conversation with John Thomson, Professor Ian Gordon suggested that such a title was 'too precious' and proposed 'Hilltop' instead, citing a quotation from Donne 'about truth standing high on a hilltop and he who must reach it "about must, and about must go." ${ }^{\prime \prime 26}$ The appropriateness of such a title for a magazine published from Victoria College ('high above the city') appealed, although certain reviewers regarded it as too bucolic to be taken seriously.

Following the receipt of copy, McKenzie Thornton Cooper objected to 'some rather strong language' in a story entitled 'Sixty' by a now forgotten author. ${ }^{27}$ The piece was withdrawn, but among those stories and poems which found their way into the first number were contributions by David Ballantyne, James K. Baxter, Alistair Campbell, Louis Johnson, Bill Oliver, Kendrick Smithyman, and Pat Wilson, an impressive range of authors, several of whose presence in a Victoria College magazine may be explained by a note on the title page, which stressed that Hilltop 'is not a student magazine... . It exists for all writers, in New Zealand and outside.'

The issue opened with stories by Philip Wilson and David Ballantyne, while John Thomson, writing as 'John Mansfield,' contributed a (for him) rare piece of fiction. Jim Winchester, communist, controversialist and, as Alistair Campbell reminded us in his autobiographical piece in the last issue of New Zealand Studies, 'King of Quiz', responded to Thomson's request for an article with a piece critical of what Winchester termed the 'basic emptiness' of Monte Holcroft's ideas, as expressed in Holcroft's series of three expansive ruminations on New Zealand society and culture, republished in 1950 by Caxton Press as Discovered Isles.

Eric Schwimmer, so prominent in Broadsheet and later Arachne made his only contribution to Hilltop in the form of an un-attributed translation of a poem by the Dutch poet Edgar du Perron..$^{28}$ Schwimmer's 
absence from Hilltop accords with his criticism of the first issue in a review published in Salient in which he judges Hilltop as generally unsuccessful, and takes particular issue with the title and what he regards as a consequent lack of clear editorial policy or leadership. ${ }^{29}$ Schwimmer's criticism was to be a factor in the transmutation of Hilltop into Arachne following the shift of editorial control to Schwimmer and Hubert Witheford after Thomson departed for Britain in September 1949.

It is the poetry content of this first issue of Hilltop which stands out as most worthy of comment. Poems by Bill Oliver, Alistair Campbell and Pat Wilson constitute the magazine's strongest link with Broadsheet, while contributions by James K. Baxter and Louis Johnson add depth to the new title. Baxter first enrolled at Victoria University College in 1950, and he occasionally attended Hilltop editorial meetings, although without taking any active part in preparing the magazine. ${ }^{30}$ However, I like to think that he may be one of the 'two anonymous coeditors' credited with assisting with the first issue of Arachne. ${ }^{31}$

Apart from Schwimmer's criticism in Salient, responses to the contents if not the format of the first issue of Hilltop were generally encouraging. Kendrick Smithyman sent his congratulations and submitted a poem for inclusion in the second number. Charles Brasch did likewise after John Thomson, Bill Oliver and Lorna Clendon stayed with him in Dunedin in mid-1949 while the editorial trio were on a trip south selling subscriptions prior to the publication of the second issue. ${ }^{32}$

The second issue opened with an editorial opposing compulsory military training, a subject which also gained a good deal of space in Salient at the time. In addition to poems by Smithyman and Brasch, Hilltop 2 also featured work by Campbell, Witheford and Baxter. The most notable contribution to the issue was Campbell's, all three of his poems being later republished. 'At the Fishing Settlement' and 'Landscape with Figures' (re-titled 'The Return') were taken into his first collection, Mine Eyes Dazzle, and both were subsequently much anthologised. 'Girl and Landscape' became 'Blonde Girl' in Wild Honey. ${ }^{34}$ These poems were written on a working holiday in the South Island. ${ }^{35}$ Campbell also offered a defence of Holcroft in response to Winchester's article in the first issue, in the form of a letter to the editor. Another item of interest is an article by Baxter, 'Why Writers Stop Writing,' described in its subtitle as: 'An adaptation and synopsis of a talk given to the Literary Society of Victoria University College, 27th May, 1949'.

A request for a grant of $£ 100$ from the New Zealand Literary Fund following the publication of the second issue was turned down, apparently because the Committee did not consider Hilltop to have properly established itself as an ongoing concern. ${ }^{36}$ In fact, the Fund made only one grant towards the publication of a literary periodical during the early years of its operation, to the New Zealand Women Writers' Society for the publication of the 1948 edition of Quill. ${ }^{37}$ It was not until 1951, when grants began to made to Reeds to assist the publication of the New Zealand Poetry Yearbook, that periodical titles began to feature to a small extent in the lists of Literary Fund recipients. Landfall began to receive regular grants from 1952.

As part of the application for funding Literary Society treasurer Lorna Clendon prepared a financial statement which indicates that issue runs for the magazine had increased from an initial four hundred to an ambitious one thousand copies with the second number. However, she also records only one hundred and fifty-five subscriptions to Hilltop at the time of the application, indicating a perhaps unrealistic reliance on casual sales. ${ }^{38}$

One source of funding which committee members did tap successfully was advertising. As John Thomson recalled in 1958, their enthusiasm for the new venture was apparently infectious.

Pat Wilson's poetic nature often came forth with picturesque ideas 'Let's hire a Tiger Moth and drop leaflets over Wellington.' He proved extremely good at securing advertisements and we would set off for an afternoon's tour of possible sources, stopping every now and then at a pub for a drink. The advertisers were, in the main, most gracious towards us and I remember only one bookshop where we were more or less ushered out. At one stage I found myself sitting on the step outside the printers hurriedly writing the text for a second-hand shop advertisement 
which hired dinner suits. We were not selective about advertisements - at the stage we could not afford to be and saw nothing incongruous in the fact that there was a butcher's advertisement in a literary magazine. We were later criticised severely on this score. ${ }^{39}$

As a result of their enterprise the back pages of both Hilltop and Arachne sport a variety of advertisements, ranging from book shops such as Parsons, Souths, and Modern Books to the Florida Milk Bar ('For Everything Hot or Cold') and Whale's butchery. While the reactions of advertisers to particular contributions occasionally caused problems for the editors, these had less impact than the objections of the printers. Income from advertising sources met a fairly substantial part of Hilltop's costs, rising from $£ 18$ for the first issue to $£ 22$ for the second, set against total expenses of $£ 69 / 11$ s and $£ 105 / 10$ s respectively. ${ }^{40}$

The cover illustration by John Drawbridge was used again for the third issue, which appeared in September 1949 and which opened with a belated attempt to establish a coherent editorial policy. This had been a major subject of Schwimmer's criticism, and was a further motivation behind the alteration of the title of Hilltop to Arachne in 1950. Oliver, to whom the editorial is ascribed by Weir and Lyon in their bibliography of his work, ${ }^{41}$ asserts that '[i]nsofar as this magazine has any policy, it is to print as much poetry, fiction, polemic and scholarship, as we, in fallibility, judge good.' Although he largely shuns engagement with a number of then current literary and cultural controversies, one aspect of Oliver's editorial which did have repercussions in Arachne were his comments on the publication by Caxton Press of a collection of poems by William Hart-Smith. ${ }^{42}$ As part of a wider criticism of Caxton's recent list of publications, Oliver describes Hart-Smith's volume as 'mediocre' and suggests that work by Allen Curnow, Basil Dowling, Pat Wilson or Alistair Campbell would have been more suitable for such an imprint. His linking of Wilson and Campbell with the more established names of Curnow and Dowling indicates a wider critical strategy behind Oliver's comments. This final issue of Hilltop appeared just prior to the emergence of Campbell as a new and significant voice in New Zealand poetry, signalled by his first collection, Mine Eyes Dazzle, published in 1950 by Robin Muir and Albion Wright of Pegasus Press in what Noel Waite has described as 'an elegant octavo edition'. ${ }^{43}$ This volume was to go through two further editions in the following six years and was favourably reviewed both locally and overseas. $^{44}$

\section{IV}

\section{$\mathrm{H}$ ILLTOP WAS SUCCEEDED in 1950 by Arachne. The} change in title signalled an increasing degree of distance between the magazine and the institution in which it had its origins. Schwimmer had already protested in print and privately that Hilltop's attempt to develop itself into a magazine of national interest was hindered both by its explicit association with Victoria College, and by its use of what he considered to be an unfortunately bucolic title. ${ }^{45}$ Several options for a new title were canvassed before Arachne was chosen, including 'Capricorn,' ${ }^{\prime 6}$ and 'The Victorian and Antarctic Review. ${ }^{\prime 47}$ With Thomson's departure from New Zealand in late 1949, Schwimmer and Witheford determined to transform the Literary Society magazine into a publication with a more international focus. Intended as a miscellany of some 130 pages, it was hoped to partly finance the proposed magazine through the Literary Fund after Ormond Wilson of the Fund's Advisory Committee encouraged the Society to make an application. ${ }^{48}$ Arachne's break with Hilltop is most clearly expressed in a note printed on the verso of an unbound slip wrapped across the cover of the first issue of the new magazine, identifying it as 'formerly Hilltop.' Probably penned by Eric Schwimmer, ${ }^{49}$ this amounts to a manifesto of the new generation, a generation soon to be given eloquent voice by Baxter at the 1951 Writers' Conference.

Hilltop was founded at the beginning of this year with the conscious absence of any policy except to publish the best work available. That work, however, apparently so heterogeneous, was found to have certain qualities which now seem to make possible a magazine centring around certain specific principles. In the nineteen-thirties some poets 
and essayists, using the facts of New Zealand's history and geography endeavoured to create a myth which would give the New Zealand writer a setting in time and space and an accepted function in his community. Arachne sets out with the principle that there is no such easy solution to the absence of anchorage in the world. We should explore, not obscure the situation of a culture in which each writer and artist is NOT part of a continuous tradition but must deliberately select from the past those influences which seem necessary to him, must accept another master than the community. This situation is at present most easily grasped in colonial societies. Perhaps the older countries are on the way to it. If this is so some sort of international context for Arachne becomes possible.

In the first issue of Arachne these ideas are suggested rather than expounded. In later issues we shall endeavour to work out their implications - to create a unity which may stimulate the diversity of contributions we hope Arachne, like Hilltop, will receive..$^{50}$

Schwimmer put these objectives somewhat more obscurely in his editorial to the first number, a recasting of the Arachne myth in terms which emphasise the plight of the artist unappreciated by her society.

While the first issue of Arachne followed Hilltop in being published by the Victoria University College Literary Society, responsibility for subsequent issues was transferred to a newly formed company, Crocus
Publishing, set up largely for that purpose by members and former members of the Society, including Schwimmer, Witheford and Oliver. Recurring difficulties had been encountered with the printer McKenzie Thornton Cooper, mostly due to disputes over the contents of the magazine, leading to a gap of 15 months between the first and second issues. Following the establishment of Crocus Publishing, Albion Wright's Pegasus Press was engaged as printer. Wright became involved partly through his publication of Alistair Campbell's first volume of poems, the preparation of which he discussed with Schwimmer. ${ }^{51}$ Their association was to continue with Schwimmer's editing of the Department of Maori Affairs quarterly $\mathrm{Te}$ Ao Hou, printed by Pegasus Press.

Another impetus towards the shift off-campus was the response of the student body to Arachne's first appearance, voiced most clearly in a review published in Salient. The author was critical of the change of title from Hilltop and dismissive of most of the contents of Arachne with the exception of a story by Helen Shaw and the exchange between Oliver and HartSmith. The reviewer concluded with the following comment, which must have been typical of many responses to student literary endeavour during mid-century.

I feel that Arachne is no credit to V.U.C., reeking as it does of intellectual snobbery, and perhaps, as at least two members of the editorial committee are no longer members of the Association, and aren't legally entitled (I understand) to be members of clubs this year, the group might well - for the sake of the good name - be discouraged from using 'Victoria College' on their cover. ${ }^{52}$

All three issues of Arachne sported a cover page illustration by Mervyn Taylor, a spider in its web. The first issue opened with an impressive selection of eight poems by Charles Spear, all of which were reprinted later the same year in his collection Twopence Coloured, ${ }^{53}$ as was his single contribution to the second number of Arachne. His poem 'Die Pelzenaffen,' published in the third issue, had already appeared in the Canterbury College publication Gaudeamus, ${ }^{54}$ and was later included by Louis Johnson in the second New Zealand Poetry Yearbook. ${ }^{55}$

Eric Schwimmer contributed a number of items to the issue, after his absence from the pages of the last two numbers of Hilltop. Apart from his editorial, these include a translation of Albert Camus's essay 'The Actor,' and a piece called 'Diary Notes,' consisting of largely unedited ruminations on a range of subjects, including, the literary hoax perpetrated by the 18th century poet, Thomas Chatterton, whose work Schwimmer was studying at the time, perhaps significantly so in the light of the First Placard.

Imaginative prose in the first issue of Arachne includes a story by Helen Shaw, who also contributed a story and an article to the final number of the magazine as well as acting as Auckland editorial representative for the issue. The Euro- 
pean theme initiated by Schwimmer was extended in an article by H.H. Rex on the existentialism of Sartre, while Witheford discussed Pound's recently published Pisan Cantos, all contributing to the avowedly international outlook of the journal. In addition to the opening selection of verse by Charles Spear, poetry by Lorna Clendon, Kendrick Smithyman and Louis Johnson was also published in the issue.

It was over a year before the second number of Arachne appeared, in February 1951. A note to subscribers slipped into the issue (signed by Judith Wild, treasurer of the Literary Society and a Director of Crocus Publishing), apologised for the delay in publication, blaming it on 'printing difficulties, which are not likely to recur.'

It appeared early last year that the V.U.C. Literary Society could not continue to bear the fairly heavy liabilities involved in publishing the magazine. The Students' Association had shown considerable generosity but could not continue to give undue prominence to efforts like ours. We, therefore, joined with some other Wellington writers, most of them graduates of Victoria College, and formed a Company, modestly named 'The Crocus Publishing Co. Ltd.'

A third issue of Arachne was promised for July of $1951,{ }^{56}$ although it did not in fact appear until December.

The second issue opens with an editorial, probably attributable to Bill Oliver, which sets out to clarify the magazine's editorial policy further. In order to survive in such a small market, the magazine must be all things to all readers, providing a venue for both conventional and unconventional fiction, poetry, and prose, while at the same time attempting to 'print work that has a cathartic quality' for the development of literature, both within New Zealand and internationally. These ideas were further explored by Hubert Witheford in an essay entitled 'Background to a Magazine,' in which he describes New Zealand society as being riven by isolation and disintegration, salvageable only by the formation of some new ethic, as yet undiscovered.

Oliver follows his editorial with an article on the poetry of William Wordsworth. He also contributes a poem, 'A Figure at the Window,' previously published in the Arts Year Book for $1950^{57}$ and later gathered into his collection Fire Without Phoenix. ${ }^{58}$ Elsewhere in the issue are poems by Alistair Campbell, Charles Spear, and Basil Dowling, while Schwimmer contributes a translation of Marcel Bisiaux's story 'The Convent.' He also provides a detailed review of collections of poetry by Alistair Campbell and Hubert Witheford, both published by Albion Wright of the Pegasus Press as part of his New Zealand Poets Series. Schwimmer regards the publication of the two volumes as a triumph for the sort of poetry published by Arachne. The issue closes with an advertisement placed by Louis Johnson, calling for contributions of verse to the inaugural issue of the New Zealand Poetry Yearbook.
V

$\mathrm{T}$ HE FINAL NUMBER of Arachne is dated December 1951. It was edited by Louis Johnson, Eric Schwimmer, Hubert Witheford, and members of the Literary Society, while Helen Shaw and Basil Dowling were respectively named as Auckland and Dunedin associate editors. The contents include a story by Shaw and poetry by Charles Spear, Witheford, Baxter and Johnson. Overall, it was a particularly strong number, but, as so often happens with university-based magazines, the natural dispersal of editorial staff following their graduation led to this being the final issue of Arachne. Wilson, Oliver, and Witheford all followed Thomson's example and departed for Britain. However, despite this dispersal of personnel, the Wellington Group, as the Arachne poets were becoming known, was well and truly established. This had become particularly evident after Louis Johnson, fortified by his involvement with the VUC magazines, turned his energy towards the production of other periodicals, including the New Zealand Poetry Yearbook and, from 1954, Numbers.

Moreover, in addition to gaining publication of their work by Pegasus Press, several of the poets who apprenticed their craft at VUC during the half-dozen or so years following the end of the war also came in for honourable mention in Baxter's hugely influential paper to the 1951 New Zealand Writers' Conference: 
The more extreme and experimental aspects of New Zealand poetry are apparent in Arachne (nee Hilltop), an irregular periodical issued under the aegis of Victoria College. Most of the poets contributing have had their best work printed in Landfall. It has been valuable as a catalyst, promoting the combination of many elements; or to change the metaphor, as a ground for testing crops. Through it, and by personal contact, a group of younger poets writing in Wellington have experienced that indispensable exchange of ideas which leads to better judgement and a genuine impetus. The poetry of W. H. Oliver, P. S. Wilson and Alistair Campbell, whatever their dissimilarities, has this in common - it is a fresh start, drawing from earlier New Zealand poets only that material which seems relevant to a new situation. ${ }^{59}$

A new generation of poets and a new poetic sensibility had clearly arrived. $\infty$

STEPHEN HAMILTON is currently researching and writing the centennial history of the Victoria University Students Association.

\section{Notes}

1 A number of people have contributed to the preparation of this paper. I would like to gratefully acknowledge the assistance and advice of Bill Oliver, Alistair Te Ariki Campbell, Eric Schwimmer, Hubert Witheford, Pat Wilson, and the late John Mansfield Thomson. I would also like to thank Terry Sturm for his role at a critical earlier stage of the work; and Vincent $\mathrm{O}^{\prime}$ Sullivan and my colleagues in the Stout Centre for their continuing interest and support.

2 Spike 1946: 47.

3 Unattributed, 'Literary Society,' Spike 1947 47.

4 Pat Wilson confirms that 'counting Vol.2,
Nos $5 / 6$ as one, there were only five issues of the Broadsheet.' Pat Wilson, letter to author, 13 March 1993. The bibliographical details of items referred to in Broadsheet, Hilltop, and Arachne are given in the appended indexes to the magazines.

5 James Bertram, 'Literary Periodicals,' Spike 1954: 40. Reprinted in Flight of the Phoenix: Critical Notes on New Zealand Writers (Wellington: Victoria University Press, 1985) 60-65.

6 Attributions made by Eric Schwimmer, letter to the author, 25 March 1993.

7 Alistair Campbell, interview with the author, 9 July 1992.

8 Eric Schwimmer, letter to the author, 25 March 1993.

9 Alistair Campbell, Island to Island (Christchurch: Whitcoulls, 1984) 111.

10 Unattributed, 'Introductory Phrases,' Broadsheet 2.3 (n.d.): n.pag. This unsigned editorial was probably written by Eric Schwimmer. Eric Schwimmer, letter to the author, 25 March 1993.

11 Triad, 'Ern Malley and the Angry Penguins,' Spike 1944: 30-31.

12 W.H. Oliver, letter to the author, 2 November 1992. Pat Wilson, letter to the author, 13 March 1993. Schwimmer, letter to the author, 25 March 1993.

13 Schwimmer, letter to the author, 25 March 1993.

14 Michael King, Frank Sargeson: A life (Auckland: Viking, 1995) 279

15 Harry Roskolenko and Elisabeth Lambert, 'Comment by the Editors of this Issue,' Voices: A Quarterly of Poetry: Australian Issue 118 (1944): 3-4.

16 Schwimmer, letter to the author, 25 March 1993. This was probably A Second Summary (Melbourne: Reed \& Harris, 1944). Schwimmer sent me his personal copy of this volume for inspection. For a review of A Second Summary see S. Musgrove, 'Confound Their Language,' Meanjin Papers 3.3 (1944): 188-189.

17 Wilson, letter to the author, 13 March 1993. Wilson's emphasis.

18 Schwimmer, letter to the author, 25 March 1993.

19 David Ballantyne, 'An American Influence,' Islands 31-32 (1981): 41.

20 Alistair Campbell, interview with the author, 9 July 1992.

21 Broadsheet 2.4 (June 1948): inside back cover page.

22 Ray Thornton, McKenzie Thornton Cooper, letter to J.M. Thomson, 19 January 1949. John Mansfield Thomson, private papers.

23 Allen Curnow, ed., A Book of New Zealand Verse: 1923-45 (Christchurch: Caxton
Press, 1945).

24 J.M. Thomson, interview with the author, 6 July 1992. James Bertram also described Hilltop in these terms in his article in Spike on literary periodical activity at Victoria College between 1949 and 1954. Bertram, 'Literary Periodicals' 40.

25 J.M. Thomson, circular letter, 21 January 1949. Thomson Papers.

26 Thomson, 'Hilltop ... outline of its origins' (unpublished essay, 30 July 1958) 5. Donne's lines are reproduced on a mockup of a proposed advertising slip for Hilltop: 'On a huge hill Cragged, and steep, truth stands, and he that will Reach it, about must, and about must go.' Thomson Papers.

27 Roy Thornton, letter to "The Editor, "Hill Top,"' 16 March 1949. J.M. Thomson, letter to R. Thornton, 26 March 1949. Thomson Papers.

28 Eric Schwimmer, letter to the author, 25 March 1993.

29 F.[sic] Schwimmer, 'In Mountain Air,' Salient 4 May 1949: 3. A defence of the magazine by Hugh Mason was published alongside Schwimmer's review.

30 Frank McKay, The Life of James K. Baxter (Auckland: Oxford University Press, 1990) 126.

31 The other may have been Louis Johnson.

32 Thomson, 'Hilltop ... outline of its origins' 5-6.

33 Alistair Campbell, Mine Eyes Dazzle: Poems 1947-49 (Christchurch: Pegasus Press, 1950).

34 Alistair Campbell, Wild Honey (London: Oxford University Press, 1964).

35 Campbell, Island to Island 115.

36 P.A. Lawlor, Secretary of the New Zealand Literary Fund Advisory Committee, to The Editor, Hilltop, 25 October 1949. Thomson Papers.

37 The New Zealand Literary Fund: 1946-1970 (Wellington: Government Printer, 1970) 6.

38 Lorna Clendon to Ormond Wilson, 24 August 1949. Thomson Papers.

39 In a footnote to this latter point, Thomson adds, 'By Eric Schwimmer, particularly.' Thomson, 'Hilltop ... outline of its origins' 3 .

40 Clendon, letter to Ormond Wilson, 24 August 1949.

41 Fr. John E. Weir and Barbara A. Lyon, New Zealand Poetry: A Select Bibliography, 1920-1972 (Christchurch: The Library, University of Canterbury, 1977) 420.

42 The subsequent exchange between HartSmith and Oliver appeared in the first issue of Arachne.

43 The Oxford Companion to New Zealand Literature, eds. Roger Robinson and 
Nelson Wattie (Melbourne: Oxford University Press: 1998) 435.

44 See Weir and Lyon, Bibliography 145.

45 Eric Schwimmer, 'In Mountain Air,' Salient 4 May 1949: 3. 'The argument against the title Hilltop was simply that it connoted Victoria College and we no longer felt identified with the alma mater as most of us were leaving or had left and Lou Johnson had never been at Victoria.' Eric Schwimmer, letter to the author, 25 March 1993.

46 Suggested by Frank Stockman in an undated note to John Thomson. Thomson Papers.

47 Schwimmer suggests the latter title 'has a Witheford flavour.' Schwimmer, letter to author, 25 March 1993.

48 Pat Wilson, letter to Mrs Wilson, [July] 1948. Transcript supplied by Wilson, letter to the author, 13 March 1993.

49 Schwimmer, letter to author, 25 March 1993.

50 Note published with Arachne 1.1 (January 1950). The ephemeral nature of this note, which is now missing from many copies of the issue, warrants its full transcription here.

51 Schwimmer, letter to the author, 25 March 1993.

52 Ngath-Fhaceil, 'Hilltop runs amuck', Salient 16 March 1950: 3.

53 Charles Spear, Twopence Coloured
(Christchurch: Caxton Press, 1951).

54 Charles Spear, 'Die Pelzenaffen,'

Gaudeamus 1 (April 1951): 3.

55 New Zealand Poetry Yearbook 2 (1952): 78.

56 This was originally given as June, with the typewritten word 'June' being altered by hand to 'July.'

57 Arts Year Book 6 (1950): 124.

58 W.H. Oliver, Fire Without Phoenix (Christchurch: Caxton Press, 1957) 22-23.

59 James K. Baxter, Recent Trends in New Zealand Poetry, James K Baxter as Critic, ed. Frank McKay (Auckland: Heinemann, 1978) 4 .

\section{SPORT, SOCIETY \& CULTURE IN NEW ZEALAND}

Edited by Brad Patterson. Contributors: Patrick Day, David Grant, Michael Grimshaw, Lloyd Jones, Bill Keane, Chris Laidlaw, James McNeish, Trevor Richards, Roger Robinson, Adrienne Simpson, Clare Simpson, Allan Thomas, Shona Thompson, Brian Turner, Geoff Vincent and Lydia Wevers

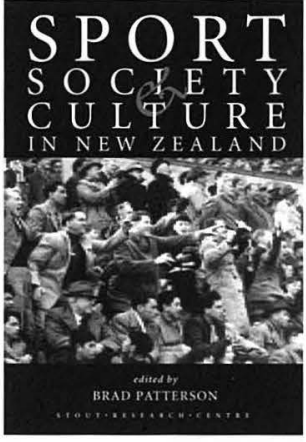

NEW ZEALANDERS LOVE SPORT. Along with reading, sport is the country's most widely engaged in leisure activity. It is the most pervasive form of communal behaviour, and even the means by which many New Zealanders define themselves. Yet, until very recently, there has been little research into the place of sport in the New Zealand cultural context, little serious writing on how sport threads and binds New Zealanders' lives.

\section{THE STOUT RESEARCH CENTRE'S OCTOBER 1998 CONFERENCE, The Real} Level Playing Field?: Sport Society and Culture, was a first attempt to promote dialogue, bringing together historians, sociologists, scholars from other disciplines, writers and sportspeople to consider from their various perspectives how sport reflects, defines and enlivens New Zealanders lives, at the same time exploring the role of sport in promoting distinctive national identity.

THIS BOOK COLLECTS 16 PAPERS PRESENTED AT THE CONFERENCE. Contributions range from the reflective and whimsical to the unabashedly empirical, even the polemical. Traditional sporting codes, as well as pursuits with lesser followings, are considered, while discussion extends to the implications of sport for religion, literature and music. Together, these papers not only provide new insights into the past and present; they also suggest promising new avenues for future inquiry.

Sport, Society \& Culture in New Zealand, edited by Brad Patterson, 183pp, ISBN 0-473-06403-0, \$24.95 from Stout Research Centre, Victoria University of Wellington, PO Box 600, Wellington, New Zealand Tel +64-4-471 5305, fax +64-4-496 5439, e-mail Stout-Centre@vuw.ac.nz 


\section{Broadsheet, Hilltop \& Arachne: Bibliographical descriptions and nominal indexes}

The following descriptions and indexes are based on an extensive study of New Zealand magazines of literary interest published during the first 60 years of the 20th century. In the case of Broadsheet, information supplied by Pat Wilson, Eric Schwimmer, Bill Oliver and Alistair Campbell has enabled the attribution of a large number of anonymous and pseudonymous contributions. Their assistance is gratefully acknowledged.

In preparing the indexes, the following conventions have been used:

- Volume and issue numbers are reduced to: 1.1, 1.2, 1.3.
- Dates are as follows: Ja, F, Mr, Ap, My, Je, Ju, Ag, S, O, N, D.

- Translations are prefaced with the abbreviation 'trans.'

- Where pseudonyms or initials are able to be linked to known authors, they are recorded in parentheses with the item contributed.

- Unidentified pseudonyms and initials are indexed by their first letter.

- Unsigned contributions which are not able to be attributed are listed under the heading 'Unattributed'.

- Untitled poems and those given the title 'Poem' or 'Song' are identified by their first line or phrase, enclosed in parentheses.

\section{BROADSHEET: THE Magazine of the Victoria University College Literary Society (title and}

\section{subtitle varies)}

Wellington: Victoria University College Literary Society, $1947-1948$.

Editors: W.H. Oliver, Pat Wilson, Alistair Campbell, Eric Schwimmer and other members of the V.U.C. Literary Society.

Printer: Mimeographed.

Irregular: No.1 - Vol.2, no. 5-6 (May 1947 August 1948).

Noteworthy contributors: Alistair Campbell, W.H. Oliver, Eric Schwimmer and Pat Wilson.

Nominal Index

'Anon', poetry: 'Poem', 1(My'47):4;

Bell, Brian, poetry: 'Rumdangle-Sqelch [sic]', 2.4(Je'48):7; fiction: 'Pater Noster', 2.4(Je'48):3-6;

Brown, Denzil, article: ('D.J.B.'), 'Ursula Bethell', 2(Ag'47):5-6;

Campbell, Alistair, poetry: ('A.C.'), 'Love poem IV', 1(My'47):2; ('C.A.S.'), 'Poem' ('The hours like surgeons' knives had pierced him through,'),

2.3(Ap'48):N.pag:;

and W.H. Oliver ('spud'), 'Mortality', 2.56( $\left.\mathrm{Ag}^{\prime} 48\right): 18$;

fiction: and W.H. Oliver, Eric Schwimmer and Pat Wilson ('E.A.'), 'Death by dissertation', 2.3(Ap'48):N.pag.; illustration: line drawing, 2.3(Ap'48):cover page;

Ecu, Claude, poetry: 'The cat', 2.3(Ap'48): N.pag;

J.A.W., fiction: 'Short story', 1(My'47):5-6; L.J.P.H, poetry: 'At peace', 1(My'47):4; McLeod, Bruce, poetry: 'Phoenix', 2.4(Te'48):8-9;

McKenzie, M. poetry: ('M.McK.'), 'Depression', 2.5-6( $\left.\mathrm{Ag}^{\prime} 48\right): 9$;
Mabbitt, Bill, article: 'Advertisement', 1(My'47):6;

M.M., poetry: 'Room of death', 2.5-6(Ag'48):12;

Murray-Oliver, A., poetry: ('a.'), ('For us the far journey'), 2.4((Je'48):2;

('a.'), 'Lines to my son unborn', 2.5-6 $\left(\mathrm{Ag}^{\prime} 48\right): 12$;

O.D., article: review of Bookie 1 (March 1948), 2.4(Je'48):9-10;

Oliver, W.H., poetry: and Eric Schwimmer ('G.G.N.'), 'Miracle', 2.3(Ap'48):N.pag.; and Alistair Campbell ('spud'), 'Mortality', 2.5-6(Ag'48):18;

('Only the shy return'), 2.4(Je'48):cover; ('W.H.O.'), 'Partial eclipse', 2(Ag'47):2; ('J.D.K.'), 'The rival animals', 2.3(Ap'48): N.pag:;

('G.G.N.'), ('Samson came sailing the far horizon'), 2.3(Ap'48):N.pag.;

('J.D.K.Z.'), 'The Samurai', 2.5-6(Ag'48):[i]; fiction: and Alistair Campbell, Eric Schwimmer and Pat Wilson ('E.A.'), 'Death by dissertation', 2.3(Ap'48): N.pag; article: ('W.H.O.'), 'Editorial', 1(My'47):1;

Quelqu'une, poetry: ("The young ash in the wood is very slender'), 2.5-6( $\left.\mathrm{Ag}^{\prime} 48\right): 10$;

Robertson, R.T., article: "The Japanese puppet theatre - Bunraku', 2.5-6( $\left.\mathrm{Ag}^{\prime} 48\right): 13-18$;

Schwimmer, Eric, poetry: ('V.M.H.'), 'De profundis', 2.3(Ap'48):N.pag.; and W.H. Oliver ('G.G.N.'), 'Miracle', 2.3(Ap'48):N.pag.;

fiction: and Alistair Campbell, W.H. Oliver and Pat Wilson ('E.A.'), 'Death by dissertation', 2.3(Ap'48):N.pag.; articles: ('E.S.'), 'Editorial', 2( $\left.\mathrm{Ag}^{\prime} 47\right): 1-2$ ('S.E.H.'), 'Harry Roskolenko', 2.3(Ap'48): N.pag.;

('E.S.'), 'Introduction to Camus', 2.5-6

(Ag'48): 3-5;

'Introductory phrases', 2.3(Ap'48):N.pag.;
Silenus, article: 'Discussion groups', 2.4(Je'48): 10-12;

Sinclair, K.V., article: trans., 'The actor', by Albert Camus, 2.5-6( $\left.\mathrm{Ag}^{\prime} 48\right): 5-9$;

C.W. Strathern, ('hic'), poetry: 'Immortality',

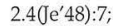
'Night', 2.4(Je'48): 1 ;

Thomson, John Mansfield, article: ('J.M.T.') 'Editorial', 2.5-6( $\left.\mathrm{Ag}^{\prime} 48\right)$ :2;

Unattributed: articles: 'An explanation', 2.4 (Je'48):[i]; 'Gordon on Mansfield', 1(My'47):1-2; 'New Zealand literature', 2.4(Je'48): 12; 'On the necessity for a national literature', 1(My'47):3;

Unger, Ralph, poetry: 'Flotsam', 2.5-6 (Ag'48):10;

'The sea is passion', 2.4(Je'48):1; 'Strife', 2.4(Je'48):2;

Wilson, Godfrey, poetry: ('G.E.A.W.'), ('August's yellow banner rushes through the gardens, $\left.{ }^{\prime}\right), 2\left(\mathrm{Ag}^{\prime} 47\right): 3$;

('G.E.A.W.'), ('Summer, singing of gentle flowers,'), 2( $\left.\mathrm{Ag}^{\prime} 47\right): 4$;

Wilson, Pat, poetry: ('C.W.B.'), 'Homage to Roskolenko', 2.3(Ap'48):N.pag; ('P.S.W.'), 'Legend', 2.5-6(Ag'48):11; ('J.H.T.'), 'The quest that never was', 2.3(Ap'48):N.pag.;

('P.S.W.'), 'Two groups', 1(My'47):4; ('P.S.W.), 'Where the schoolboys walk', 2.5-6( $\left.\mathrm{Ag}^{\prime} 48\right): 11$; fiction: and Alistair Campbell, W.H. Oliver and Eric Schwimmer ('E.A.'), 'Death by dissertation', 2.3(Ap'48):N.pag.; article: 'Study groups', 1(My'47):6; 


\section{HILLTOP: A Literary Magazine (subtitle varies)}

Wellington: Literary Society of Victoria University College, 1949.

Editors: John Mansfield Thomson (AprilJune 1949); W.H. Oliver (September 1949).

Printer: McKenzie, Thornton, Cooper.

Quarterly (but irregular): Vol.1, no.1 - Vol.1 no.3 (April - September 1949).

Noteworthy contributors: David

Ballantyne, James K. Baxter, Alistair

Campbell, Louis Johnson, W.H. Oliver

Kendrick Smithyman, John Mansfield

Thomson and Pat Wilson.

\section{Nominal index:}

Bagley, Maurice, fiction: 'Tom Boots', 1.1(Ap'49):18-19;

Ballantyne, David,

fiction: 'Girls have to suffer', 1.1(Ap'49):7-9;

Barker, Arthur,

poetry: trans., 'The lark', by Pierre de

Ronsard, 1.2(Je'49):9-10;

trans., 'On the choice of his burial-place', by Pierre de Ronsard, 1.2(Je'49):11-13; trans., 'Sonnets for Helen, XLIII', by Pierre de Ronsard, 1.2(Je'49):11; trans., 'To his soul', by Pierre de Ronsard, 1.2(Je'49):11;

article: 'Poems of Ronsard', 1.2(Je'49):8-9;

Baxter, James K., poetry: 'The bridge', 1.1(Ap'49):26;

'The climb', 1.1(Ap'49):26;

'Homecoming in November', 1.1(Ap'49):26;

'Night in Tarras', 1.2(Je'49):18;

'Sea change', 1.2(Je'49):18;

'Shakespeare', 1.1(Ap'49):26;

'Wellington', 1.1(Ap'49):27;

fiction: 'Blue Peter', 1.3(S'49):10-11; article: 'Why writers stop writing', 1.2(Je'49):26-27;

Benda, Harry, letter, 1.3(S'49):36;

Boyd, Mary B., article: 'Pacific review', 1.3(S'49):12-16;

Brasch, Charles, poetry: 'Sea-gulls among the mountains', 1.2(Je'49):16;

Campbell, Alistair, poetry: 'IV' ('Meeting my childhood love one day in magnificent'), 1.1(Ap'49):17; 'VII' ('Easily you move; and easily as a tree'), 1.1(Ap'49):17;

'XII: For Bill Mabbett', 1.1(Ap'49):17; 'XIII' ('Evening through the gorge'), 1.1(Ap'49):16;

'XV: The girl at the library', 1.1(Ap'49):1617;

'At the fishing settlement', 1.2(Je'49):15;

'Girl and landscape', 1.2(Je'49):14;

'Landscape with figures', 1.2(Je'49):14;

article: letter, $1.2\left(\mathrm{Je}^{\prime} 49\right): 38$;
Caselberg, John, poetry: ('Dear child'), 1.1(Ap'49):25;

('He came'), 1.1(Ap'49):25;

('This tall mountain'), 1.1(Ap'49):30;

('Two white spun clouds'), 1.1(Ap'49):25;

Clendon, Lorna,

poetry: 'Lord she is one of your children', 1.1(Ap'49):25;

'The old old lady ...' ', 1.1(Ap'49):24;

'Will the phoenix rise', 1.1(Ap'49):25;

fiction: 'The fall', 1.3(S'49):4-5;

Collin, B.E.F.S.,

poetry: 'Lissea Vara and the fair prince', 1.3(S'49):21-22;

Drawbridge, John, illustration: line drawing, 1.1(Ap'49): cover page - 1.3(S'49): cover page;

Hunter, Lois, fiction: 'The home', 1.3(S'49):23-24;

Johnson, Louis, poetry: 'Becoming', 1.1(Ap'49):31; 'Chant for ritual', 1.1(Ap'49):31; 'Poem about who', 1.1(Ap'49):31; 'Twin sons were born at the eleventh hour', 1.1(Ap'49):31; fiction: 'The eternal female', 1.3(S'49):1920;

Jones, Raymond R.F., letter, 1.3(S'49):32,34;

McGorm, Frank, fiction: 'In the beginning', 1.1(Ap'49):23-4;

Middleton, O.E. letter, 1.3(S'49):36,38;

Miles, F.F. article: 'A help to the reading of Gerard Manley Hopkins', 1.2(Je'49):35-37;

Moore, A.C., letter, 1.3(S'49):28,30;

Munz, Peter article: 'An idea of history', 1.2(Je'49):5-7;

Murray-Oliver, A.A., article: 'Film notes: "Soviet Youth Parade, 1945"', 1.1(Ap'49):37,39;

Oliver, W.H poetry: 'Advice at the entrance to purgatory', 1.1(Ap'49):13; 'A ballad of the sunburnt mountain', 1.1(Ap'49):12;

'The old stone house', 1.3(S'49):7-9;

'Sea legend', 1.1(Ap'49):13;

'The story of a mermaid', 1.1(Ap'49):12; articles: and Hubert Witheford, editorial, 1.2 $\left(\mathrm{Je}^{\prime} 49\right): 3-4$;

'Editorial', 1.3(S'49):3;

O'Shea, John, fiction: 'The ants', 1.3(S'49):5-7;

Robertson, R.T., article: 'Early America - early New Zealand', 1.1(Ap'49):20-22;
Schwimmer, Eric, poetry: trans., 'Twentieth century', by Edgar du Perron, 1.1(Ap'49):6;

Smith, J. Cameron, poetry: 'The comic', 1.3(S'49):18; 'The lullaby', 1.3(S'49):18-19;

Smith, Ron, letter, 1.2(Je'49):38;

Smithyman, Kendrick, poetry: 'View of the city, in oil', 1.2(Je'49): 15;

Summers, John, letter, 1.3(S'49):32-34;

Sutton-Smith, Brian, poetry: 'Peter $\mathrm{Pan}^{\prime}, 1.1\left(\mathrm{Ap}^{\prime} 49\right): 13$; fiction: 'Before the jubilee', 1.2(Je'49):1924; article: and Pat Wilson, letter, 1.3(S'49):28;

Thompson, Barbara, articles: 'Marionette theatre', 1.2(Je'49):2425;

'The Tempest with wood and string', 1.3(S'49):25-26;

Thomson, John Mansfield, fiction: ('John Mansfield'), 'The gods descend: The story of a sea-side storekeeper and his unusual fate', 1.1(Ap'49):27-30; article: 'Half-way house', review of The Middle of the Joumey, by Lionel Trilling, and Other Voices Other Rooms, by Truman Capote, 1.1(Ap'49):33-37;

Unattributed, article: 'The stork', 1.3(S'49):38;

Wilson, Pat, poetry: 'From an old portrait', 1.1(Ap'49):14; 'Isabel and the sea', 1.1(Ap'49):14; 'A second tableau', 1.1(Ap'49):14; 'Time for bed', 1.1(Ap'49):15; 'To whom it may please you', 1.1(Ap'49):15;

'Waste labour', 1.1(Ap'49):15; 'World views of history', 1.2(Je'49):28-34; 'Wrapped in time's veil', 1.1(Ap'49):14; article: and B. Sutton-Smith, letter, 1.3(S'49):28;

Wilson, P. J., fiction: 'In the tunnel', 1.1(Ap'49):3-6;

Winchester, J.W. article: 'The widening gulf: A note on Holcroft', 1.1(Ap'49): 10-11;

Witheford, Hubert, poetry: 'Afternoon', 1.2(Je'49):17; 'At the cavern mouth', 1.2(Je'49):17; 'Lake seen through pine branches', 1.3(S'49):17;

'The magnolia Tree', 1.3(S'49):17.

'Tempest', 1.2(Je'49):16;

'The words', 1.3(S'49):17; article: and W.H. Oliver, editorial, 1.2(Je'49):3-4

Wright, Olive, letter, 1.3(S'49):30,32; 


\section{ARACHNE: A Literary Journal (subtitle varies)}

Wellington: Victoria University College Literary Society (January 1950 - February 1951); Crocus Publishing (December 1951).

Editorial committees: Hubert Witheford, Eric Schwimmer, W.H. Oliver, Lorna Clendon, 'and two anonymous co-editors' (January 1950); W.H. Oliver, Eric Schwimmer, Hubert Witheford and the Victoria University College Literary Society (February 1951); Louis Johnson, Eric Schwimmer, Hubert Witheford, and the Victoria University College Literary Society with associate editors Helen Shaw (Auckland) and Basil Dowling (Dunedin) (December 1951).

Printers: McKenzie, Thornton, Cooper (January 1950); Pegasus Press (February December 1951).

Quarterly (but irregular): Vol.1, no.1 - Vol.1, no.3 (January 1950 - December 1951).

Noteworthy contributors: James K. Baxter, Charles Brasch, Alistair Campbell, Basil Dowling, Yvonne du Fresne, J.R. Hervey, Louis Johnson, W.H. Oliver, Eric

Schwimmer, Helen Shaw, Kendrick Smithyman, Charles Spear, Pat Wilson and Hubert Witheford.

Noteworthy artist: Mervyn Taylor.

\section{Nominal index:}

Alcock, Peter, poetry: 'Chorus one', 1.2(F'51):16; 'Dispossession', 1.2( $\left.\mathrm{F}^{\prime} 51\right): 15$;

'He rests. He has travelled', 1.2( $\left.\mathrm{F}^{\prime} 51\right): 16$;

'Thunder in the oaks', 1.2( $\left.\mathrm{F}^{\prime} 51\right): 15$; article: 'The gleaming lens', 1.2(F'51):3235;

Baxter, James K., poetry: 'Elegy 1944', 1.3(D'51):20-21;

Boyd, Mary M., article: 'Pacific review 2', $1.1\left(\mathrm{Ja}^{\prime} 50\right): 27,29,31,33,35$;

Brasch, Charles, article: 'Lebanon', review of Impressions of a Unesco Conference, by M.H. Holcroft, 1.1(Ja'50):35,37;

Campbell, Alistair, poetry: 'Coming of spring', 1.2( $\left.\mathrm{F}^{\prime} 51\right): 10$; 'Death of Hylas: Nymphs' song', 1.2( $\left.\mathrm{F}^{\prime} 51\right): 10$;

'From the Persian', 1.2(F'51):10-11; reference to: Eric Schwimmer, 'New attitudes in New Zealand poetry', 1.2(F'51):28-31;

Clendon, Lorna, poetry: 'To E. expostulating on an arrangement of Shakespeare's Sonnets', 1.1(Ja'50):17; articles: 'Anarchism in New Zealand', 1.1(Ja'50):8-9; letter, 1.2( $\left.\mathrm{F}^{\prime} 51\right): 36$;
Dowling, Basil, poetry: 'The morepork', 1.2( $\left.\mathrm{F}^{\prime} 51\right): 13$; 'Spring in Roxburgh', 1.2(F'51):14; 'Wanaka holiday', 1.2(F'51):14;

Du Presne [sic], Yvonne, fiction: 'Sunday', 1.2(F'51):8-9;

Entrican, E.W., poetry: 'Poem' ('Sweet water bear my body down'), 1.2(F'51):8-9;

Fraser, George, article: 'The eclipse of the market', 1.2(F'51):17-20;

Hart-Smith, W., articles: letter, 1.1(Ja'50):22; letter, 1.1(Ja'50):23-24;

Hervey, J.R., poetry: ‘On a verandah', 1.3(D'51):15;

Johnson, Louis, poetry: 'Bells', 1.3(D'51):17;

'The children', 1.3(D'51):18;

'Dear Doctor D'Ath', 1.1(Ja'50):15-16;

'Dreams', 1.3(D'51):17;

'The kiss', 1.3(D'51):17;

'The music teacher: Boarding school sonnet', 1.3(D'51):18;

'Some held to love by hate: For Benjamin Constant', 1.1(Ja'50):15;

'What frightens most', 1.3(D'51):16;

Lockett, Cherry, poetry: 'Legend', 1.3(D'51):13.

'Prayer for a wanderer', 1.3(D'51):14;

Munz, Peter, article: 'The lure of the east', review of Introduction to the Study of the Hindu Doctrines, by R. Guenon, $1.2\left(\mathrm{~F}^{\prime} 51\right): 26-27$;

Ngata, W.T., article: trans., 'Introduction to Maori poetry', by Sir Apirana Ngata, 1.3(D'51):2-7;

Oliver, W.H., poetry: 'A figure at the window', 1.2( $\left.\mathrm{F}^{\prime} 51\right): 12-13$; articles; editorial, 1.2( $\left.\mathrm{F}^{\prime} 51\right): 1-2$; "The empty country: An attitude to Wordsworth', 1.2(F'51):2-7; ('W.H.O.'), 'Pastor Niemoller', 1.1(Ja'50):39-41. letter, $1.1\left(\mathrm{Ja}^{\prime} 50\right): 22-23$;

Rex, H.H., article: 'Concerning Sartre', 1.1(Ja'50):1821;

Schwimmer, Eric,

fiction: 'I want to torpedo you', 1.3(D'51):19-20; trans., 'The convent', by Marcel Bisiaux, 1.2(F'51):23-25; articles: trans., 'The actor', by Albert Camus, 1.1(Ja'50):10-12; editorial, 1.1(Ja'50):1; 'Diary notes, 1946', 1.1(Ja'50):13-14; ('E.S.'), 'Journal for the dissatisfied', review of Here \& Now 1 (October 1949), 1.1(Ja'50):41;

'New attitudes in New Zealand poetry', review of Shadow of the Flame, Poems 1942-7, by Hubert Witheford, and Mine Eyes Dazzle, Poems 1947-49, by Alistair Campbell, 1.2(F'51):28-31;

'The place of Maori poetry', 1.3(D'51):1-2; ('E.S.'), 'Refuge in craftsmanship', review of Poetry London 17, 1.2(F'51):31;

'Valerius Flaccus as a poet', 1.2(F'51):41-44; letter, 1.2( $\left.\mathrm{F}^{\prime} 51\right): 38$;

Shaw, Helen,

fiction: 'After the dark', 1.1(Ja'50):5-8;

'The Blind', 1.3(D'51):8-13;

article: 'I am the dark: The poetry of Ursula Bethell', 1.3(D'51):25,27-29;

Smithyman, Kendrick, poetry: 'Song' ('Nor separation nor nearness'), 1.1(Ja'50):16;

Spear, Charles, poetry: '1914', 1.2(F'51):11; 'Christoph', 1.1(Ja'50):4;

'Die pelzenaffen', 1.3(D'51):7;

'Homecoming', 1.1(Ja'50):2;

'Karl' ('All day he stood at Weeping

Cross,'), 1.1(Ja'50):3;

'Karl' ('Outside among the talking crisscross reeds'), 1.1(Ja'50):2;

'Portrait', 1.1(Ja'50):2;

'Promised land', 1.1(Ja'50):3;

'Tancredi', 1.1(Ja'50):3;

'Vineta', 1.1(Ja'50):4;

Stockman, Frank, article: ('F.S.'), 'Demonstration house: A house and a handbook', 1.1(Ja'50):37,39;

Summers, John, letter, 1.2( $\left.\mathrm{F}^{\prime} 51\right): 36-38$;

Unattributed, article: 'The stork', 1.1(Ja'50):43;

Taylor, E. Mervyn, illustration: cover design, 1.1(Ja'50) - 1.3(D'51);

Trowern, Lily H., fiction: 'Happiness to Mrs Flanagan', 1.3(D'51):31-32;

Wilson, Pat, article: 'Blake on war and hunting', 1.3(D'51):22-24;

Witheford, Hubert, poetry: ('A harvest shaken on the axletree'), 1.3(D'51):15-16; articles: 'Background to a magazine', 1.2(F'51):20-23; ('H.W.'), 'The evaporation of social democracy', 1.2(F'51):39-40; 'The Pisan Cantos', 1.1(Ja'50):24-25,27; reference to: Eric Schwimmer, 'New attitudes in New Zealand poetry', 1.2(F'51):28-31; 